\title{
ERGONOMIC POSTURE ASSESSMENT OF BUTCHERS: A SMALL ENTERPRISE STUDY IN MALAYSIA FOOD INDUSTRY
}

Article history

Received

19 February 2019

Received in revised form

18 July 2019

Accepted

24 July 2019

Published online

24 October 2019

*Corresponding author msalwa@uthm.edu.my Jalan Panchor, 84600 Muar Johor, Malaysia

bErul Food Industries, Kampung Pekan Pedas, 71400 Rembau, Negeri Sembilan, Malaysia

cDepartment of Materials, Manufacturing and Industrial Engineering, School of Mechanical Engineering, Faculty of Engineering, Universiti Teknologi Malaysia, 81310 UTM Johor Bahru, Johor, Malaysia

\section{Graphical abstract}

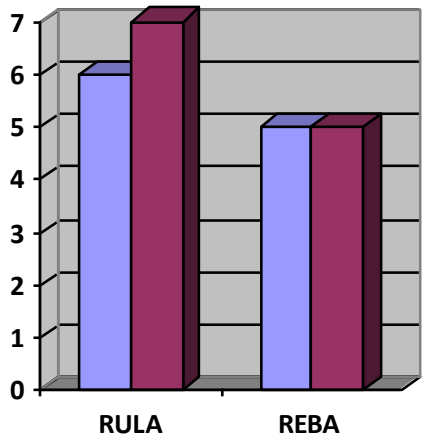

\section{Abstract}

The development of small and medium-sized enterprises (SMEs) is crucia for improving the economy of a rural area. However, this can cause working posture problems, such as musculoskeletal disorders (MSDs) and cumulative trauma disorders (CTDs). This is especially true for butchers, who work in SMEs that still depend on manual handling processes without standard operating procedures. Posture analysis evaluations using the Rapid Upper Limb Assessment (RULA) and Rapid Entire Body Assessment (REBA) tools have been used to analyse the working postures of butchers working in SMEs. The aim of this study was to identify butchers' risks of working posture problems, and to propose an ergonomic workstation designed to reduce MSDs and CTDs. This study was focused on smoked meat preparation. The butchers there spend 5-8 hours a day cutting and trimming meat. The assessment was conducted using RULA and REBA worksheets. The RULA score for the meat trimming process was 7, with a score of 6 for the meat cutting process. As for REBA, the score was 5 for both the meat trimming and meat cutting processes. Based on these scores, the butchers were at higher risks for MSDs and CTDs. Therefore, a new ergonomic workstation design was proposed based on the principles of motion economy.

Keywords: Ergonomic, musculoskeletal disorders, rapid entire body assessment, rapid upper limb assessment, posture assessment 


\begin{abstract}
Abstrak
Pertumbuhan SME adalah penting dalam meningkatkan lagi ekonomi di kawasan luar bandar. Namun, ia boleh menyebabkan masalah kesilapan postur dan posisi tubuh semasa bekerja seperti MSDs dan CTDs. Masalah ini berlaku kepada pemotong daging yang berkerja di SME yang masih melakukan kerja-kerja secara manual tanpa SOP yang baik. Analisis postur tubuh telah dinilai dengan menggunakan kaedah RULA dan REBA dimana posisi tubuh pemotong daging dinilai. Tujuan kajian ini dilakukan adalah untuk mengenal pasti risiko masalah postur tubuh badan pemotong daging dan mencadangkan tempat kerja yang ergonomik bagi mengurangkan risiko MSDs dan CTDs. Kajian ini focus kepada persiapan penyediaan daging salai. Pemotong daging memperuntukkan masa 5 jam hingga 8 jam sehari untuk proses memotong dan merapikan daging. Penilaian dilakukan menggunakan kaedah skor RULA dan REBA. Skor RULA untuk merapikan daging ialah 7 , skor 6 bagi memotong daging. Skor REBA menunjukkan skor 5 untuk kedua-dua proses memotong dan merapikan daging. Berdasarkan skor tersebut, pemotong daging berisiko tinggi untuk mengalami gejala MSDs dan CTDs. Oleh itu, tempat kerja yang ergonomik dicadangkan berdasarkan teori principle of motion economy.

Kata kunci: Ergonomik, musculoskeletal disorders, rapid entire body assessment, rapid upper limb assessment, analisis postur badan
\end{abstract}

(C) 2019 Penerbit UTM Press. All rights reserved

\subsection{INTRODUCTION}

In recent years, small and medium-sized enterprises (SMEs) have been developing rapidly, especially in rural areas. However, the increased production processes have exposed workers to working posture problems, such as musculoskeletal disorders (MSDs) and cumulative trauma disorders (CTDs). This is because knowledge and awareness of the importance of ergonomic working postures are still at a minimum in the SME industry [1]. Ergonomics is defined as the interactions between workers and workplace elements, such as machines or workstations [2]. Working posture problems, including MSDs and CTDs, are especially common in developed and developing countries [3]. The potential for working posture problems is mainly due to repetitive work [4], awkward working postures and tough working condition [1]. The production processes of the SME industry still depend on manual handling processes.

MSDs are defined as health problem that affect the ligaments, tendons, bones and muscles due to high intensity work [5]. Workers who are affected by MSDs should seek preliminary treatment, because these can lead to critical health conditions, like movement disabilities and paralysis. MSDs can also affect the company itself due to the increased expenses involved in worker compensation and healthcare for those employees who are affected by MSDs, as well as the costs related to the company's production processes [3]. CTDs are defined as health conditions in which the constant 'wear and tear' of the muscles and/or tendons prevent the injury from healing [6]. CTDs are usually caused by maintaining a static work posture for a long period of time.
MSDs include any injuries to the musculoskeletal system, including the bones, muscles and ligaments, caused by overexposure to the abovementioned risk factors and hazards in the workplace $[7,8,9]$. The results of a study by previous research work shows that MSDs were caused by poor working spaces and manual equipment handling, which force a worker to adapt to poor working condition [8]. According to the Health and Safety Executive of the United Kingdom (Figure 1) during 2016 and 2017, MSDs mainly affected the upper limbs, neck, lower limbs and back.

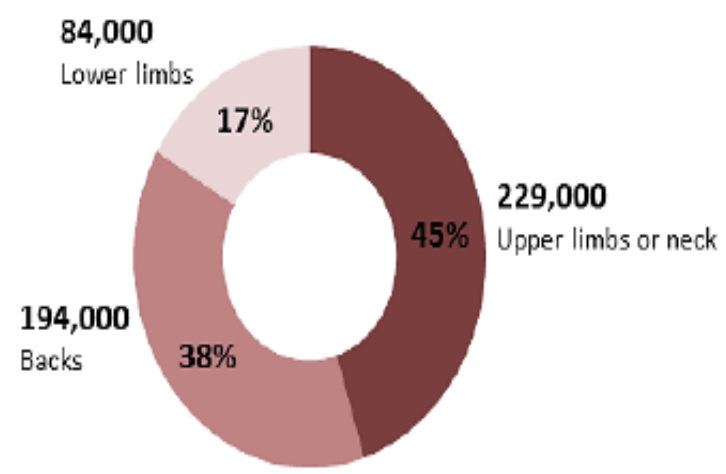

Figure 1 The affected area of MSDs [10]

CTDs are health conditions describing 'wear and tear' on the muscles, tendons and nerves that exceed the ability of the tissues to heal themselves. Moreover, CTDs are categorized by discomfort, disability and pain in the muscle, tendons and tissues that is caused by repetitive work, excessive vibration, a constraining 
work posture and forceful movement [11]. CTDs commonly affect the upper part of the body, such as the wrists. Silverstein et al. (1986) suggested that CTDs of the hands and wrists are usually caused by repetitive and forceful work. The results of the study by Mahoney (1995) showed that a CTD can be categorized as a chronic injury caused by a heavy load or force that gradually develops over time.

According to the Department of Occupational Safety and Health Malaysia statistics, an increasing number of MSD cases has been reported, from 10 cases in 2005 to 675 cases in 2014 [2]. Problems related to MSDs of poultry meat industry are severe in developing countries because of poor working condition and lack of effective preventive programs contributing in high rates of musculoskeletal symptoms [12]. This shows that awareness regarding the importance of ergonomic working postures is still lacking in poultry meat industries.

The aim of this study was to identify and analyse the working posture problems of the butchers by using Rapid Upper Limb Assessment (RULA) and Rapid Entire Body Assessment (REBA) analyses. The RULA and REBA are observationally based techniques used to quantitatively measure human postures, and to evaluate any discomfort and postural strain due to poor body positioning. Additionally, a more ergonomic workstation design for the butchers has been proposed in order to reduce the MSD and CTD risks and overcome the working posture problems.

\subsection{LITERATURE REVIEW}

Ergonomics is defined as the study of the relationship between workers and their working environment [1, 4]. More specifically, ergonomics consists of designing a working environment that is more compatible with the workers, rather than forcing the workers to physically adapt to the working environment [13]. An ergonomic working posture is important, because it can reduce the risk of injuries caused by poor working conditions. According to Occupational Health and Safety Council of Ontario (2007), poor working postures are usually associated with repetitive work, stress, strain, constant force and excessive vibration [14].

The RULA is an ergonomic observation method that is used to evaluate the risk of working posture problems, specifically MSDs. The RULA was originally intended as an objective measurement of the MSD risk during inactive work periods $[15,16,17]$. It is based on an evaluation of work posture problems, such as static movement, repetitive work, external forces and the work duration, related to the arms, trunk, neck, legs and wrists [17]. Four action levels must be observed in order to obtain the score in a RULA analysis.

The REBA shares the same work posture analysis principle as the RULA with regard to the evaluation of body parts and work posture problems [18]. In a REBA analysis, the body parts are divided into sections, and the score is calculated based on the movement planes and muscle activity [3]. Five levels of action are used to determine the score, including articular angle measurements, force or load observations, movement repetitiveness and the postural change frequency.

The major difference between the RULA and the REBA is the analysis of the profession or job scope. The results of this study showed that the REBA is a more efficient evaluation for the service sector. The REBA is also focused on an analysis of the entire body when compared to the RULA, which is only focused on an analysis of the upper body. Therefore, the RULA more suitable for analysing sedentary and seated work, while the REBA is better for analysing both static and dynamic work.

The principles of motion economy include the characteristics of easy movement, which refers to minimizing the number of movements while performing work, with an objective of improving a worker's productivity [19]. The basic principles are to eliminate unnecessary motion, reduce the cycle time and reduce the MSD and CTD risks. There are three principles of work design involved in motion economy: the use of the human body, the arrangement of the workplace and the design of the tools and equipment.

The principle of motion economy is an ergonomic guideline which is invented by Frank B. Gillbreth and improvised by R. M. Barnes to facilitate the work performance of a worker who is performing repetitive and mechanical works with definite steps [20]. It gives better movement of an operator while performing any tasks, minimizing workers fatigue and eliminate unwanted workers movement while doing their tasks. Work and workplace arrangement should well design to ensure jobs can be done in the most productive manner [21].

\subsection{Previous RULA and REBA Studies}

Previously, no research had been done in RULA and REBA specifically for butcher at Malaysia food industries. However, an evaluation of ergonomics risk factors had been done among meat cutter in India [8]. This study aims to investigate the nature and magnitude of WMSDs among manual meat cutters. This study used direct observation, questionnaires, interview and photography or measure the ergonomic risk factors. The finding of this study shows that posture analysis indicated high risk especially for mincing task, which is need further investigation for reducing the risks factors.

Table 1 shows the previous work posture research including RULA and REBA analyses in different industries. 
Table 1 Previous research on RULA and REBA

\begin{tabular}{|c|c|c|c|c|}
\hline Author/s & Method/s & Sector & Research & Result and Recommendation \\
\hline [8] & REBA & Food Industry & $\begin{array}{l}\text { Study are focused } \\
\text { on meat cutter in } \\
\text { India for repetitive } \\
\text { task specifically in } \\
\text { mincing process. }\end{array}$ & $\begin{array}{l}\text { The result show that the meat } \\
\text { cutter is in high risk since the works } \\
\text { is repetitive for long hour a day. } \\
\text { Results suggest that ergonomic } \\
\text { interventions that address retooling } \\
\text { and workstation and process } \\
\text { redesign would be useful in } \\
\text { reducing the number of injuries. }\end{array}$ \\
\hline \multirow[t]{2}{*}{ [13] } & $\begin{array}{l}\text { RULA and } \\
\text { REBA }\end{array}$ & $\begin{array}{l}\text { Clothing } \\
\text { Industry }\end{array}$ & $\begin{array}{l}\text { Study are focused } \\
\text { on } 60 \text { males tailor } \\
\text { that work on job } \\
\text { task of stitching, } \\
\text { ironing, and } \\
\text { cutting. }\end{array}$ & $\begin{array}{l}\text { The result for RULA shows that } 40 \% \\
\text { of tailors are in risk of MSDs in } \\
\text { cutting, } 55 \% \text { for stitching, and } 65 \% \\
\text { for ironing. For REBA, the cutting } \\
\text { activities show that } 5 \% \text { are at risk of } \\
\text { MSDs, } 35 \% \text { for stitching, and } 30 \% \\
\text { for ironing. }\end{array}$ \\
\hline & & & & $\begin{array}{l}\text { The ergonomic workstation is } \\
\text { suggested to reduce the risk of } \\
\text { MSDs. }\end{array}$ \\
\hline [22] & REBA & $\begin{array}{l}\text { Engine Oil } \\
\text { Company }\end{array}$ & $\begin{array}{l}\text { Study on } 40 \text { jobs } \\
\text { scopes with } 123 \\
\text { different tasks. For } \\
\text { each jobs scope, } \\
\text { only one task is } \\
\text { selected to be } \\
\text { analyzed by REBA. }\end{array}$ & $\begin{array}{l}\text { The result found that the risk work } \\
\text { posture problem is in low and } \\
\text { moderate level. } \\
\text { As a recommendation, further } \\
\text { investigation is needed to be done } \\
\text { on selected workstations. }\end{array}$ \\
\hline \multirow[t]{2}{*}{ [23] } & $\begin{array}{l}\text { RULA and } \\
\text { REBA }\end{array}$ & $\begin{array}{l}\text { Manufacturin } \\
\text { g Industry }\end{array}$ & $\begin{array}{lr}\text { The } & \text { study } \\
\text { conducted on } 15 \\
\text { workers } & \text { that } \\
\text { engage } & \text { with } \\
\text { different job task. }\end{array}$ & $\begin{array}{l}\text { From the analysis, RULA } \\
\text { determined that } 40 \% \text { of workers } \\
\text { are on higher risk and REBA } \\
\text { analysis recorded } 53 \% \text { of workers } \\
\text { are at higher risk of MSDs. }\end{array}$ \\
\hline & & & & $\begin{array}{l}\text { The recommendation that } \\
\text { proposed is the immediate } \\
\text { implementation of ergonomic } \\
\text { knowledge among workers and } \\
\text { implement the law on SMEs } \\
\text { industry. }\end{array}$ \\
\hline \multirow[t]{2}{*}{ [24] } & \multirow[t]{2}{*}{ RULA } & \multirow[t]{2}{*}{$\begin{array}{l}\text { Manufacturin } \\
\text { g Industry }\end{array}$} & \multirow[t]{2}{*}{$\begin{array}{lr}\text { This study } & \text { has } \\
\text { performed } & \text { an } \\
\text { evaluation } & \text { of } \\
\text { workstation } & \text { for } \\
\text { workers. } & \end{array}$} & $\begin{array}{l}\text { The score for RULA evaluation is } 5 \text {. } \\
\text { It shows that further investigation is } \\
\text { required with immediately } \\
\text { changes. } \\
\text { The recommendation is to design } \\
\text { an ergonomic chair as shown in } \\
\text { Figure } 2 \text {. }\end{array}$ \\
\hline & & & & 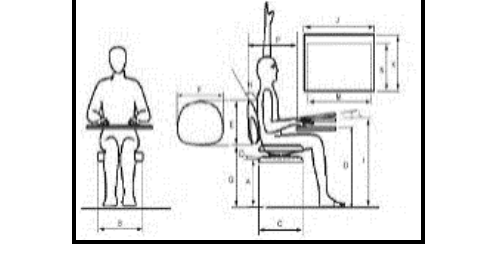 \\
\hline
\end{tabular}

Figure 2 Ergonomic chair

\begin{tabular}{cccc}
\hline [25] RULA & $\begin{array}{c}\text { Seafood } \\
\text { Processing }\end{array}$ & $\begin{array}{c}\text { The study is focused } \\
\text { on the processing }\end{array}$ & $\begin{array}{l}\text { The RULA score for both processes } \\
\text { is 5. 5. The workers are in medium }\end{array}$ \\
\hline
\end{tabular}




\begin{tabular}{|c|c|c|c|c|}
\hline Author/s & Method/s & Sector & Research & Result and Recommendation \\
\hline & & Industry & $\begin{array}{l}\text { of raw fish including } \\
\text { the trimming and } \\
\text { filleting process. }\end{array}$ & $\begin{array}{l}\text { risk of MSDs due to the repetition } \\
\text { work. } \\
\text { The suggested improvement is to } \\
\text { change the way of holding a knife } \\
\text { and change the position of items } \\
\text { in the working tables as shown in } \\
\text { Figure } 3 \text { (a) for filleting and Figure } 3 \\
\text { (b) for trimming. }\end{array}$ \\
\hline & & & & $\begin{array}{l}\text { Figure } 3 \text { (a) Filleting process } \\
\text { improvement }\end{array}$ \\
\hline & & & & $\begin{array}{l}\text { Figure } 3 \text { (b) Trimming process } \\
\text { improvement }\end{array}$ \\
\hline [26] & $\begin{array}{l}\text { RULA and } \\
\text { REBA }\end{array}$ & $\begin{array}{l}\text { University } \\
\text { Personnel/Offi } \\
\text { ce Workers }\end{array}$ & $\begin{array}{l}\text { The study is } \\
\text { conducted over } 72 \\
\text { workers to analyze } \\
\text { the work posture } \\
\text { and their } \\
\text { workstation to } \\
\text { provide the } \\
\text { information for the } \\
\text { future design of } \\
\text { ergonomic } \\
\text { computer } \\
\text { workstation. }\end{array}$ & $\begin{array}{l}\text { The result shows that analysis of } \\
\text { RULA is on average score } 5 \text { and for } \\
\text { REBA are on average score } 4 \text {. } \\
\text { The solution is by designing new } \\
\text { computer workstation with several } \\
\text { important consideration factors } \\
\text { such as monitor position, seat } \\
\text { adjustability, and keyboard or } \\
\text { mouse design. }\end{array}$ \\
\hline [27] & REBA & $\begin{array}{l}\text { Mining } \\
\text { Industry }\end{array}$ & $\begin{array}{l}\text { The study is } \\
\text { conducted on } 18 \\
\text { workers that carried } \\
\text { out wet screening } \\
\text { job. }\end{array}$ & $\begin{array}{l}\text { The result from REBA analysis is a } \\
\text { score of } 8.24 \text {. The score shows the } \\
\text { workers are on the higher risk of } \\
\text { MSDs. } \\
\text { The recommended solution is to } \\
\text { improve the work process, design } \\
\text { workstation, and improving work } \\
\text { posture of workers. }\end{array}$ \\
\hline \multirow[t]{2}{*}{ [28] } & $\begin{array}{l}\text { RULA and } \\
\text { REBA }\end{array}$ & $\begin{array}{l}\text { Forging } \\
\text { Industry }\end{array}$ & $\begin{array}{l}\text { The study is } \\
\text { conducted on } 130 \\
\text { workers engaged } \\
\text { with the various job } \\
\text { scope in the small } \\
\text { forging industry. }\end{array}$ & $\begin{array}{l}\text { The result from REBA shows that } \\
10.65 \% \text { of workers are at the higher } \\
\text { risk of MSDs and required } \\
\text { immediate changes. The result } \\
\text { from RULA shows that } 30 \% \text { of } \\
\text { workers are at the higher risk of } \\
\text { MSDs. }\end{array}$ \\
\hline & & & & $\begin{array}{l}\text { The solution that proposed is the } \\
\text { implementation of ergonomic } \\
\text { intervention with the proper } \\
\text { awareness among workers. }\end{array}$ \\
\hline
\end{tabular}




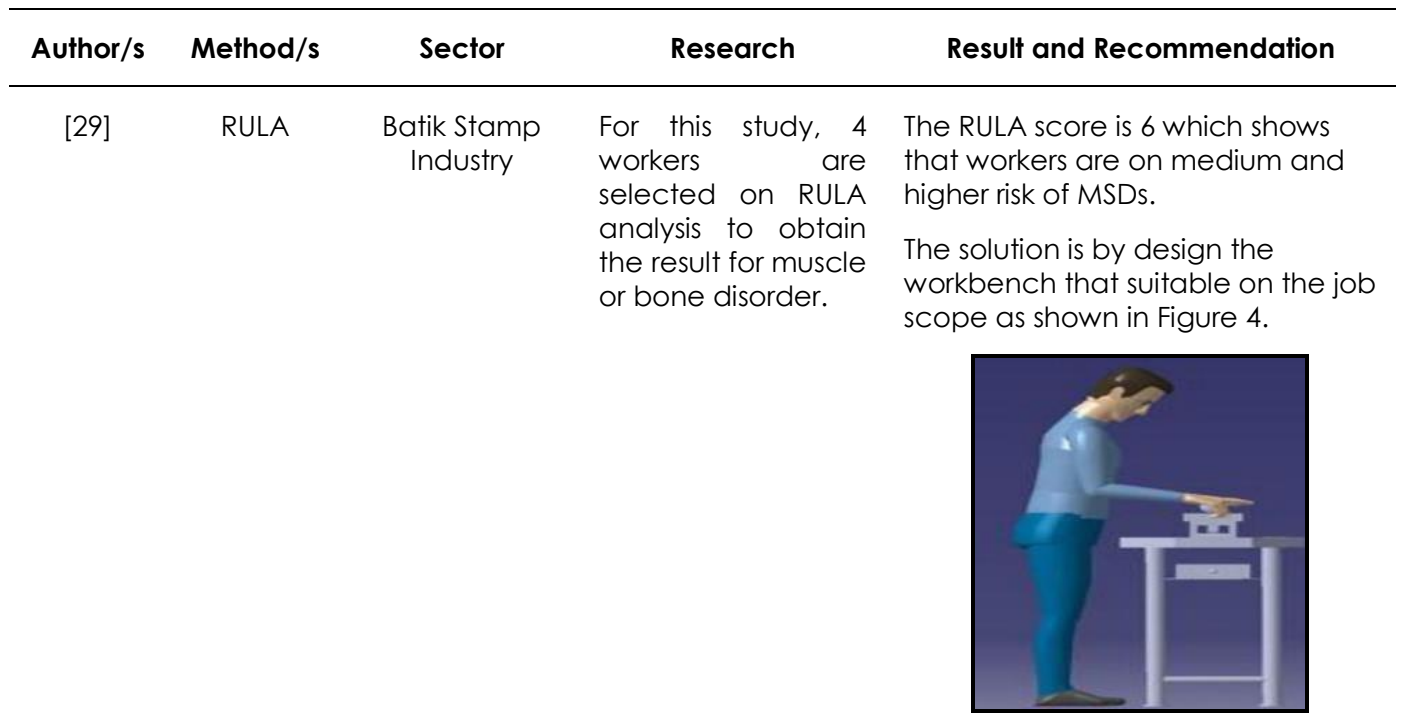

Figure 4 Standing workbench

\begin{tabular}{|c|c|c|c|c|}
\hline \multirow[t]{2}{*}{ [30] } & REBA & $\begin{array}{l}\text { Agri- } \\
\text { Machinery } \\
\text { Industry }\end{array}$ & $\begin{array}{l}\text { The study is } \\
\text { conducted on } 10 \\
\text { workers of an } \\
\text { assembly unit. }\end{array}$ & $\begin{array}{l}\text { The study showed that } 60 \% \text { of } \\
\text { workers have a very high risk of } \\
\text { MSDs, } 30 \% \text { of the high risk, and } 30 \% \\
\text { of the medium risk. }\end{array}$ \\
\hline & & & & $\begin{array}{l}\text { The study recommends the proper } \\
\text { awareness of ergonomic training } \\
\text { to the workers and changes of the } \\
\text { working environment. }\end{array}$ \\
\hline \multirow[t]{2}{*}{ [31] } & $\begin{array}{l}\text { RULA and } \\
\text { REBA }\end{array}$ & $\begin{array}{c}\text { School } \\
\text { Workshop }\end{array}$ & \multirow{2}{*}{$\begin{array}{l}\text { The study is done at } \\
\text { the secondary } \\
\text { school with student } \\
\text { ages from } 13 \text { to } 15 \\
\text { years old. There are } \\
93 \text { work postures } \\
\text { being analysed. }\end{array}$} & $\begin{array}{l}\text { The result for RULA score shows an } \\
\text { average of } 4.87 \text { and for REBA } \\
\text { score is } 5.87 \text {. This shows that the risk } \\
\text { of work posture problem is medium } \\
\text { and need further action. }\end{array}$ \\
\hline & & & & $\begin{array}{l}\text { The recommendation is by } \\
\text { intervention student about } \\
\text { ergonomic working posture, work } \\
\text { performance, and level comfort. }\end{array}$ \\
\hline \multirow[t]{2}{*}{ [32] } & RULA & $\begin{array}{l}\text { Plastic } \\
\text { Injection } \\
\text { Industry }\end{array}$ & $\begin{array}{l}\text { This study focused } \\
\text { on the job scope of } \\
\text { shoe sole trimming } \\
\text { process. }\end{array}$ & $\begin{array}{l}\text { The score for RULA is } 5 \text { which } \\
\text { means it is in medium condition } \\
\text { and further investigation is } \\
\text { needed. }\end{array}$ \\
\hline & & & & $\begin{array}{l}\text { The solution is by designing the } \\
\text { new production line and reduce } \\
\text { the working hour to } 4 \text { in this } \\
\text { workstation. }\end{array}$ \\
\hline
\end{tabular}

\subsection{METHODOLOGY}

An observational method is often used to analyse the ergonomics of the working posture in the workplace in order to determine the MSD and CTD risk factors. For this study, the RULA and REBA were chosen to analyse the working postures of butchers. The RULA and REBA analyses were conducted using worksheets. In this study, number of sample taken is one. Direct observational method is selected for obtaining best posture shoot of butcher.

\subsection{Rapid Upper Limb Assessment}

McAtamney and Corlett introduced the RULA method in 1993. The RULA is a postural assessment method used to analyse the working posture risk to the upper limbs. It is acknowledged that the RULA 
worksheet is focused on analysing the body posture, work repetitiveness and force applied while working [17]. The assessment is divided into two sections: section $A$ focuses on analysing the arms and wrists, while section $B$ focuses on the neck, trunk and legs. Based on these analyses, a RULA score is obtained to determine the work posture risks.

The RULA worksheet is used to analyse the working posture risk factors, such as movement, exertion force, repetitive work and work posture, which may affect the body, including the upper arms, lower arms, wrists, neck, trunk and legs. The steps involved in analysing the working posture using the RULA worksheet are shown in Table 2.

For the data analysis, the RULA worksheet consists of the scoring decisions used to determine the work posture risks. Table 3 shows the RULA scoring decisions. A score of 1 to 2 is considered to be an acceptable work posture. Scores from 3 to 4 and 5 to 6 show low and medium risks of work posture problems, respectively, and further investigation is required to determine the actual work posture problems. Finally, a score of 7 or more indicates a higher risk of work posture problems.

Table 2 Parameters display by OSD

\begin{tabular}{clc}
\hline Steps & \multicolumn{1}{c}{ Descriptions } & Analysis \\
\hline 1 & Locate Upper Arm Position & \\
2 & Locate Lower Arm Position & \\
3 & Locate Wrist Position & Arm and Wrist \\
4 & Locate Wrist Twist Position & Analysis \\
5 & Determine Posture Score A & \\
6 & Add Muscle Use Score & \\
7 & Add Force/Load Score & \\
8 & Find Row in Posture Score C & Neck, Trunk \\
9 & Locate Neck Position & and Leg \\
10 & Locate Trunk Position & Analysis \\
11 & Determine Legs Condition & \\
12 & Determine Posture Score B & \\
13 & Add Muscle Use Score & \\
14 & Add Force/Load Score & \\
15 & Find Column in Posture Score C \\
\hline 16 & Determine Final Score & \\
\hline
\end{tabular}

Table 3 RULA score decision

\begin{tabular}{cl}
\hline Score & \multicolumn{1}{c}{ Risk of Work Posture Problem } \\
\hline $1-2$ & Acceptable posture \\
$3-4$ & Need further investigation and changes may \\
$5-6$ & be needed \\
$7+$ & Inveed further investigation and changes soon \\
\hline
\end{tabular}

\subsection{Rapid Entire Body Assessment}

Hignett and McAtamney introduced the REBA analysis method in 2000. The REBA is an ergonomic body posture assessment method that evaluates the whole body to determine any risk factors with regard to the work posture. The REBA analysis worksheet used to evaluate the work posture, especially the body posture, movement, force exerted and work repetition. The assessment worksheet is divided into two sections: section A includes the neck, trunk and legs and section $B$ includes the arms and wrists.

The REBA worksheet was used to analyse the working posture problem risk factors with regard to the movement, exertion force, repetitive work and work posture. The steps used to analyse the working posture using the REBA worksheet are shown in Table 4.

Table 4 Steps of REBA assessment method

\begin{tabular}{|c|c|c|}
\hline Steps & Descriptions & Analysis \\
\hline 1 & Locate Neck Position & \multirow{6}{*}{$\begin{array}{c}\text { Neck, Trunk } \\
\text { and Legs } \\
\text { Analysis }\end{array}$} \\
\hline 2 & Locate Trunk Position & \\
\hline 3 & Locate Legs Position & \\
\hline 4 & Determine Posture Score A & \\
\hline 5 & Add Force/Load Score & \\
\hline 6 & Find Row in Posture Score C & \\
\hline 7 & Locate Upper Arm Position & \multirow{7}{*}{$\begin{array}{l}\text { Arm and } \\
\text { Wrist Analysis }\end{array}$} \\
\hline 8 & Locate Lower Arm Position & \\
\hline 9 & Locate Wrist Position & \\
\hline 10 & Determine Posture Score B & \\
\hline 11 & Add Coupling Score & \\
\hline 12 & $\begin{array}{l}\text { Find Column in Posture } \\
\text { Score C }\end{array}$ & \\
\hline 13 & Add Activity Score & \\
\hline 14 & Determine Final Score & \\
\hline
\end{tabular}

The REBA data analysis consists of making decisions while determining the work posture problem risks. Table 5 shows the REBA scoring decisions. A score of 1 represents a negligible risk. Scores of 2 to 3 and 4 to 7 show low and medium risks, respectively, which require further investigation and possible changes. A score of 8 to 10 represents a higher risk, with an investigation and the implementation of a solution required. Finally, a score of 11 or more indicates a very high risk, with the implementation of a solution or recommendation being compulsory.

Table 5 REBA score decision

\begin{tabular}{|c|c|}
\hline Score & Risk of Work Posture Problem \\
\hline 1 & Negligible risk \\
\hline $2-3$ & Low risk, changes may be needed \\
\hline $4-7$ & $\begin{array}{l}\text { Medium risk, need further investigation and } \\
\text { changes soon }\end{array}$ \\
\hline $8-10$ & $\begin{array}{l}\text { High risk, need further investigation and } \\
\text { implementation soon }\end{array}$ \\
\hline $11+$ & Very high risk, implementation soon \\
\hline
\end{tabular}

\subsection{RESULTS AND ANALYSIS}

\subsection{Meat Cutting RULA Analysis}

Section A consists of the analysis of the upper arm, lower arm and wrist positions. Figure 5 shows the RULA analysis based on the angles obtained from the body posture for the upper arm (a), lower arm (b) and wrist 
(c). Table 6 shows the analysis score based on the data provided in Figure 5.

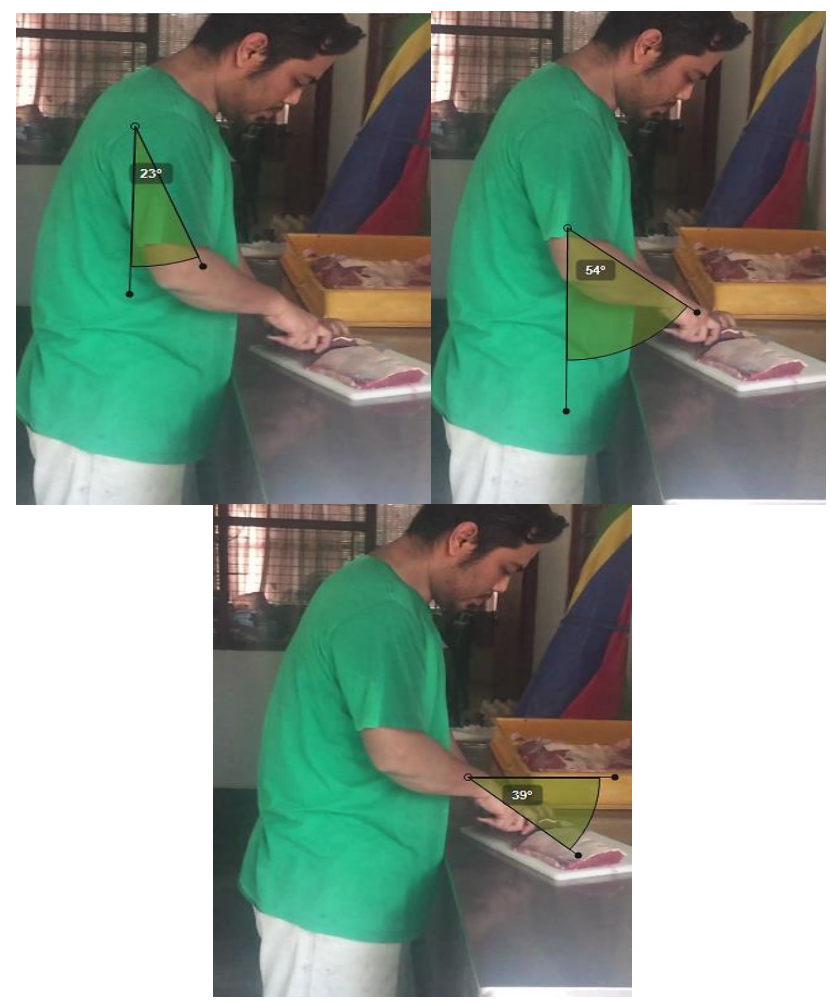

Figure 5 Upper arm, lower arm, and wrist analysis for RULA

Table 6 RULA analysis assessment score for the upper arm, lower arm, and wrist analysis

\begin{tabular}{cll}
\hline Score & \multicolumn{1}{c}{ Analysis } & \multicolumn{1}{c}{ Descriptions } \\
\hline+2 & Upper Arm Position & $\begin{array}{l}\text { Upper arm position is } \\
\text { flexion for } 23^{\circ} .\end{array}$ \\
+1 & Lower Arm Position & $\begin{array}{l}\text { Lower position is flexion } \\
\text { for } 54^{\circ} .\end{array}$ \\
+3 & Wrist Position & $\begin{array}{l}\text { Wrist position is flexion } \\
\text { for } 39^{\circ} .\end{array}$ \\
+1 & Wrist Twist Position & $\begin{array}{l}\text { Wrist is twisted in the } \\
\text { mid-range position. }\end{array}$ \\
+1 & Muscle Use Score & \begin{tabular}{l} 
Repeated movement. \\
\hline
\end{tabular}
\end{tabular}

For section $B$, the RULA worksheet focuses on the body posture of the neck, trunk and legs. Figure 6 shows the analysis of a butcher's body posture, which includes determining the angles of the body posture for the neck (a) and trunk (b). Table 7 shows the RULA worksheet analysis based figures captured.

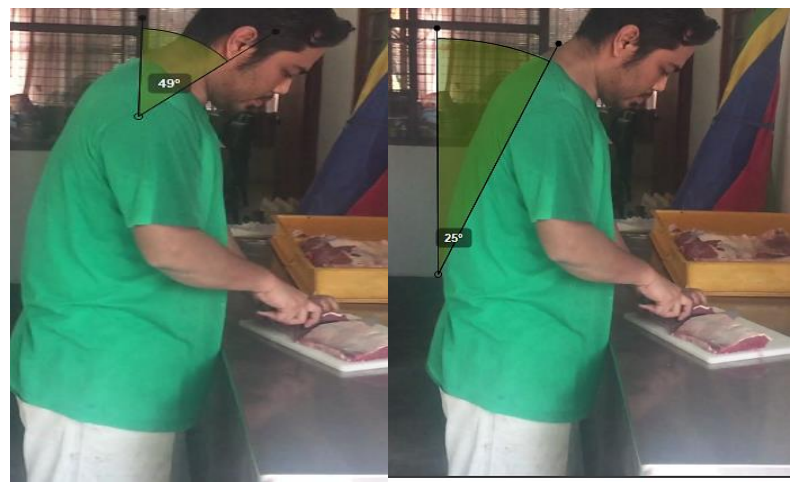

Figure 6 Neck and trunk analysis for RULA

Table 7 RULA analysis assessment score for neck and trunk analysis

\begin{tabular}{ccl}
\hline Score & \multicolumn{1}{c}{ Analysis } & \multicolumn{1}{c}{ Descriptions } \\
\hline+3 & Neck Position & $\begin{array}{l}\text { Neck position is flexion for } \\
49^{\circ} .\end{array}$ \\
& $\begin{array}{l}\text { Trunk position is flexion for } \\
25^{\circ} . \\
\text { Legs position is assumed to } \\
\text { unsupported due to the legs } \\
\text { position cannot be seen in } \\
\text { the video. }\end{array}$ \\
& Trunk Position & Legeated movement. \\
+2 & Muscle Use Score & $\begin{array}{l}\text { Repead ition } \\
\text { Load lower than } 2 \mathrm{~kg} .\end{array}$ \\
+1 & Force/Load Score &
\end{tabular}

\subsection{Meat Trimming Process RULA Analysis}

Section A consists of an analysis of the positions of the upper arms, lower arms and wrists. Figure 7 shows the RULA analysis based on the angles obtained from the body posture for the upper arm (a), lower arm (b) and wrist (c). Table 8 shows the RULA worksheet analysis based on the data provided.

Table 8 RULA analysis assessment score for neck and trunk analysis

\begin{tabular}{|c|c|c|}
\hline Score & Analysis & Descriptions \\
\hline+2 & Upper Arm Position & $\begin{array}{l}\text { Upper arm position is } \\
\text { flexion for } 31^{\circ} \text {. }\end{array}$ \\
\hline+1 & Lower Arm Position & $\begin{array}{l}\text { Lower position is flexion } \\
\text { for } 75^{\circ} \text {. }\end{array}$ \\
\hline+4 & Wrist Position & $\begin{array}{l}\text { Wrist position is flexion for } \\
31^{\circ} \text {. }\end{array}$ \\
\hline+1 & Wrist Twist Position & $\begin{array}{l}\text { Wrist is twisted in the } \\
\text { mid-range position. }\end{array}$ \\
\hline+1 & Muscle Use Score & Repeated movement. \\
\hline+0 & Force/Load Score & Load is lower than $2 \mathrm{~kg}$. \\
\hline
\end{tabular}




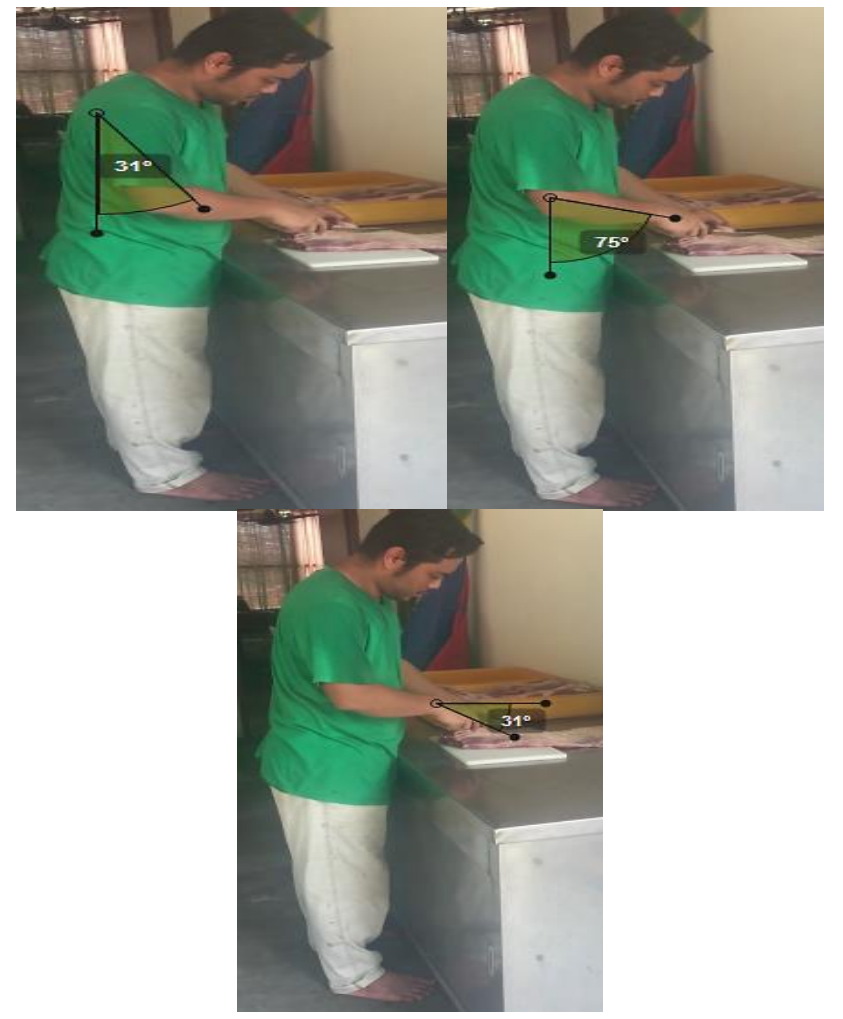

Figure 7 Upper arm, lower arm, and wrist analysis for RULA

For section $B$, the RULA worksheet analysis focuses on the body posture for the neck, trunk and legs. Figure 8 shows the analysis of a butcher's body posture with regard to the neck (a), trunk (b) and leg (c) by determining the angle of each body posture. Table 9 shows the RULA worksheet analysis based on the data obtained from figures captured.

Table 9 RULA assessment score for the neck and trunk analysis

\begin{tabular}{|c|c|c|}
\hline Score & Analysis & Descriptions \\
\hline+3 & Neck Position & $\begin{array}{l}\text { Neck position is flexion for } \\
45^{\circ} \text {. }\end{array}$ \\
\hline+3 & Trunk Position & $\begin{array}{l}\text { Trunk position is flexion for } \\
25^{\circ} \text {. }\end{array}$ \\
\hline+2 & Legs Position & $\begin{array}{l}\text { Legs position is not } \\
\text { supported by another } \\
\text { element. }\end{array}$ \\
\hline+1 & Muscle Use Score & Repeated movement. \\
\hline+0 & Force/Load Score & Load is lower than $2 \mathrm{~kg}$. \\
\hline
\end{tabular}

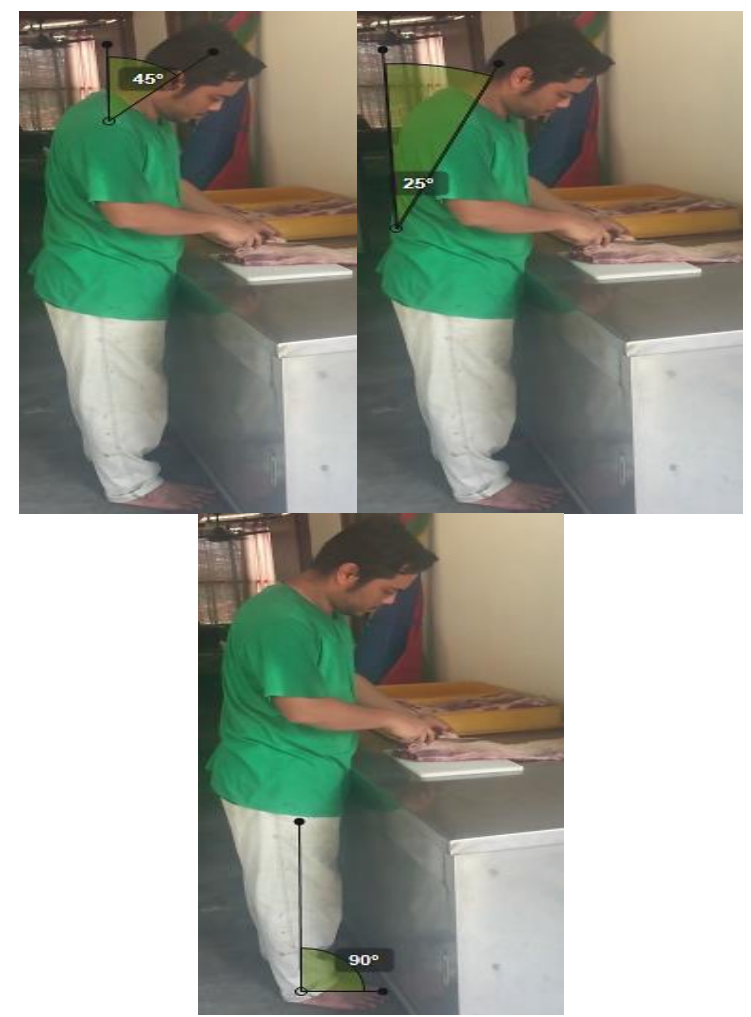

Figure 8 Neck, trunk, and leg analysis for RULA

\subsection{Meat Cutting Process REBA Analysis}

Section A consists of an analysis of the positions of the neck and trunk. Figure 9 shows the REBA analysis based on the angles obtained from the body postures of the neck (a) and trunk (b). Table 10 shows the REBA worksheet analysis based on the data provided in Figure 9.

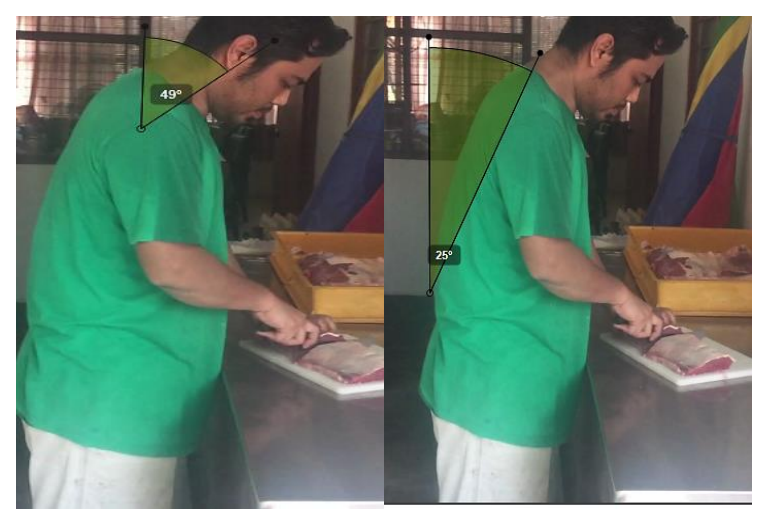

Figure 9 Neck and trunk analysis for REBA 
Table 10 REBA assessment score for the neck and trunk analysis

\begin{tabular}{|c|c|c|}
\hline Score & Analysis & Descriptions \\
\hline+2 & Neck Position & $\begin{array}{l}\text { Neck position is flexion for } \\
49^{\circ} \text {. }\end{array}$ \\
\hline+3 & Trunk Position & $\begin{array}{l}\text { Trunk position is flexion for } \\
25^{\circ} \text {. }\end{array}$ \\
\hline+1 & Leg Position & $\begin{array}{l}\text { Legs position is assumed } \\
\text { bending for } 90^{\circ} \text { due to the } \\
\text { leg position cannot be } \\
\text { seen in the video. }\end{array}$ \\
\hline+0 & Force/Load Score & Load is lower than $2 \mathrm{~kg}$. \\
\hline
\end{tabular}

For section $B$, the REBA worksheet analysis focuses on the body postures of the upper arms, lower arms and wrists. Figure 10 shows the analysis method with regard to the butcher's body posture including the upper arm (a) and lower arm (b) by determining the angle of each body posture. Table 11 shows the RULA worksheet analysis based on the data obtained in Figure 10.

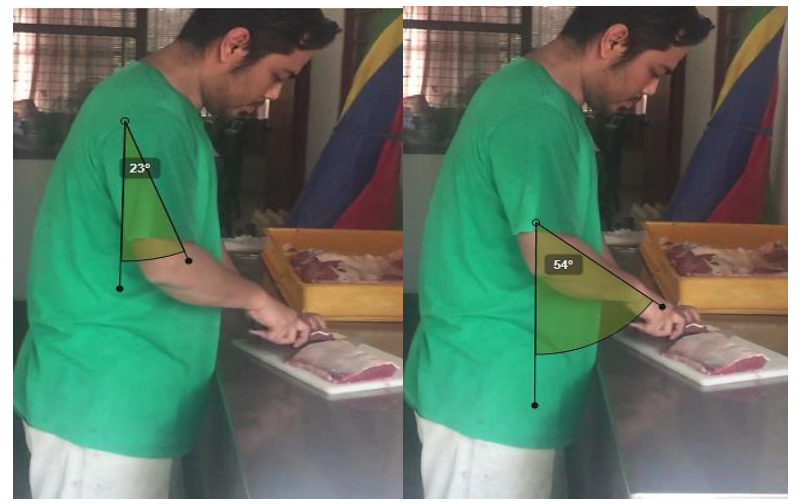

Figure 10 Upper arm and lower arm analysis for REBA

Table 11 REBA assessment score for the upper arm, lower arm, and wrist position analysis

\begin{tabular}{|c|c|c|}
\hline Score & Analysis & Descriptions \\
\hline+2 & Upper Arm Position & $\begin{array}{l}\text { Upper arm is flexion for } \\
23^{\circ} \text {. }\end{array}$ \\
\hline+1 & Lower Arm Position & $\begin{array}{l}\text { Lower arm is flexion for } \\
54^{\circ} \text {. }\end{array}$ \\
\hline+2 & Wrist Position & Wrist is flexion for $39^{\circ}$. \\
\hline+0 & Coupling Score & $\begin{array}{l}\text { Well-fitting handle and } \\
\text { mid-range power grip. }\end{array}$ \\
\hline+1 & Activity Score & $\begin{array}{l}\text { Repeated small range } \\
\text { actions (more than } 4 \\
\text { times per minute). }\end{array}$ \\
\hline
\end{tabular}

\subsection{Meat Trimming Process REBA Analysis}

Section A consists of an analysis of the positions of the neck, trunk and legs. Figure 11 shows the REBA analysis based on the body posture angles obtained for the neck (a), trunk (b) and leg (c). Table 12 shows the REBA worksheet analysis based on the data provided in Figure 11.
Table 12 REBA assessment score for the neck and trunk position analysis

\begin{tabular}{cll}
\hline Score & \multicolumn{1}{c}{ Analysis } & \multicolumn{1}{c}{ Descriptions } \\
\hline 2 & Neck Position & $\begin{array}{l}\text { Neck position is flexion for } \\
45^{\circ} .\end{array}$ \\
3 & Trunk Position & $\begin{array}{l}\text { Trunk position is flexion for } \\
25^{\circ} .\end{array}$ \\
& Legs position is straight for \\
1 & Leg Position & $\begin{array}{l}90^{\circ} . \\
\text { Load is lower than } 2 \mathrm{~kg} .\end{array}$ \\
\hline
\end{tabular}

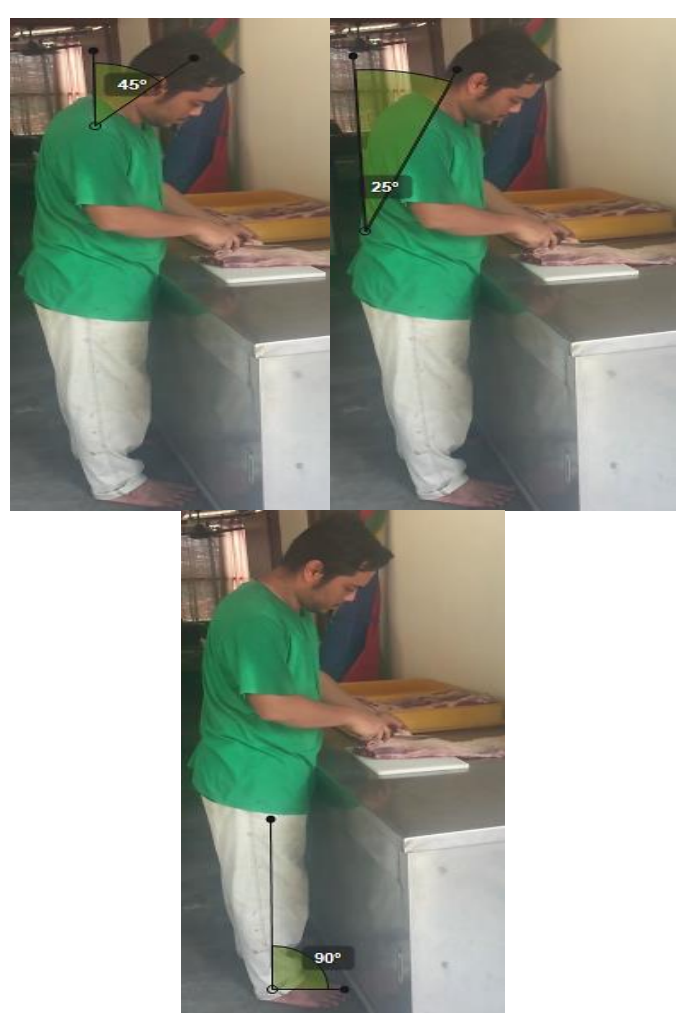

Figure 11 Neck and trunk analysis for REBA

For section $B$, the REBA worksheet analysis focuses on the body postures of the upper arms, lower arms and wrists. Figure 12 shows the REBA analysis method for a butcher's body posture, including the upper arm (a), lower arm (b) and wrist (c), by determining the angle for each body posture. Table 13 shows the REBA worksheet analysis based on the data obtained in Figure 12. 


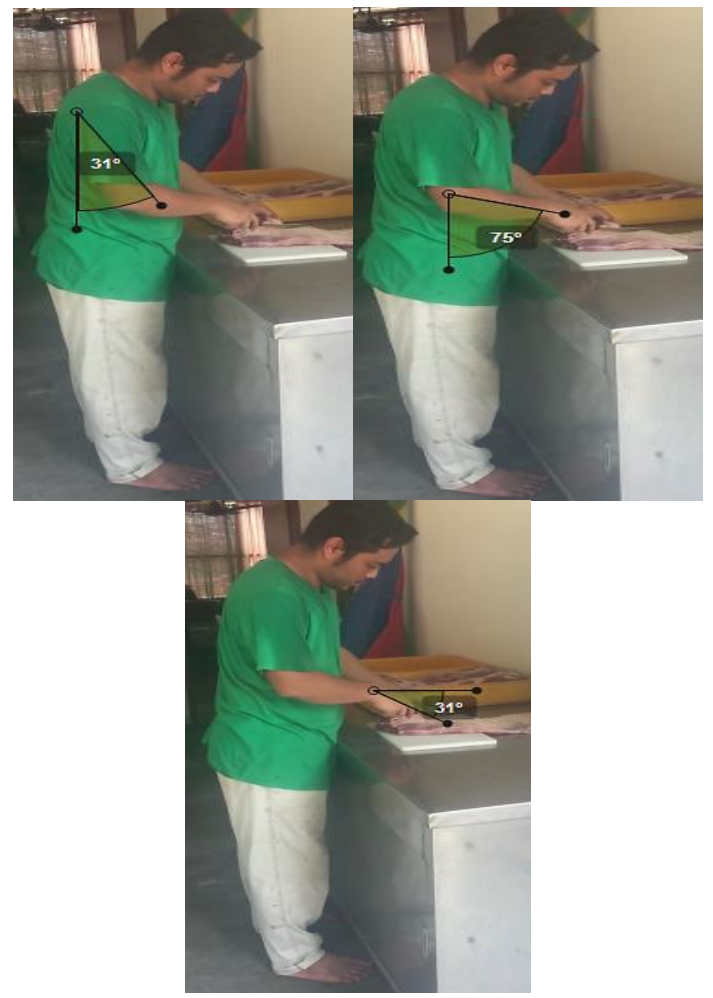

Figure 12 Upper arm, lower arm, and trunk analysis for REBA

Table 13 REBA assessment score for the upper arm, lower arm, and wrist position analysis

\begin{tabular}{|c|c|c|}
\hline Score & Analysis & Descriptions \\
\hline+2 & Upper Arm Position & $\begin{array}{l}\text { Upper arm is flexion for } \\
31^{\circ} \text {. }\end{array}$ \\
\hline+1 & Lower Arm Position & $\begin{array}{l}\text { Lower arm is flexion for } \\
75^{\circ} \text {. }\end{array}$ \\
\hline+3 & Wrist Position & $\begin{array}{l}\text { Wrist is flexion for } 31^{\circ} \text { and } \\
\text { twisted from the midline. }\end{array}$ \\
\hline+0 & Coupling Score & $\begin{array}{l}\text { Well-fitting handle and } \\
\text { mid-range power grip. }\end{array}$ \\
\hline+1 & Activity Score & $\begin{array}{l}\text { Repeated small range } \\
\text { actions (more than } 4 \\
\text { times per minute). }\end{array}$ \\
\hline
\end{tabular}

\subsection{Analysis Result}

Table 14 shows the RULA analysis for both meat preparation processes: cutting and trimming the meat. In the RULA analysis, the work posture was divided into two different sections: section $\mathrm{A}$ for the arm and wrist analysis and section B for the neck, trunk and leg analysis. Based on the analysis, the final RULA score for the meat cutting working posture was 6 , and the score for meat trimming was 7 . Both of the processes fell into the high risk category for work posture problems, such as MSDs and CTDs.
Table 14 RULA assessment analysis

\begin{tabular}{lcc}
\hline \multirow{2}{*}{ RULA Analysis } & \multicolumn{2}{c}{ Scoring } \\
\cline { 2 - 3 } A. Arm and wrist analysis & 2 & 2 \\
meat & $\begin{array}{c}\text { Trimming } \\
\text { meat }\end{array}$ \\
\hline Locate upper arm position & 1 & 1 \\
Locate lower arm position & 3 & 4 \\
Locate wrist position & 1 & 1 \\
Wrist twist & 3 & 4 \\
Posture score A & 1 & 1 \\
Muscle use score & 0 & 0 \\
Force/Load score & 4 & 5 \\
Wrist and arm score & & \\
\hline B. Neck, trunk, and leg & & 3 \\
analysis & 3 & 3 \\
\hline Locate neck position & 3 & 2 \\
Locate trunk position & 2 & 5 \\
Legs & 5 & 1 \\
Posture score B & 1 & 0 \\
Muscle use score & 0 & 6 \\
Force/Load score & 6 & $\mathbf{7}$ \\
Neck, trunk, leg score & $\mathbf{6}$ & \\
\hline Final Score & &
\end{tabular}

The bar graph shown in Figure 13 indicates the RULA analysis scores for the meat cutting and trimming process for each part of the analysis. The scores for the upper arms, wrist twisting, neck, trunk, legs, muscle use and force/load were the same for both processes. However, there were differences between the scores for the lower arm and wrist positions. The score for the meat trimming process was slightly higher when compared to the meat cutting process. The graph shows that the meat trimming process is associated with a higher risk of work posture problems when compared to the meat cutting process.

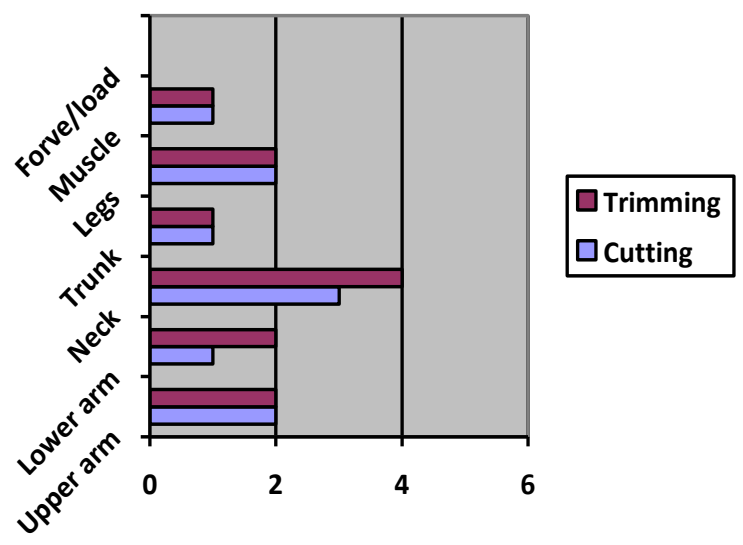

Figure 13 Analysis of the RULA score 
Table 15 REBA assessment analysis

\begin{tabular}{|c|c|c|}
\hline \multirow[b]{2}{*}{ REBA Analysis } & \multicolumn{2}{|c|}{ Scoring } \\
\hline & $\begin{array}{l}\text { Cutting } \\
\text { meat }\end{array}$ & $\begin{array}{c}\text { Trimming } \\
\text { meat }\end{array}$ \\
\hline \multicolumn{3}{|l|}{$\begin{array}{l}\text { A. Neck, trunk and leg } \\
\text { analysis }\end{array}$} \\
\hline Locate neck position & 2 & 2 \\
\hline Locate trunk position & 3 & 3 \\
\hline Legs & 1 & 1 \\
\hline Posture score A & 4 & 4 \\
\hline Force/Load score & 0 & 0 \\
\hline Score A & 4 & 4 \\
\hline \multicolumn{3}{|l|}{ B. Arm and wrist analysis } \\
\hline Locate upper arm position & 2 & 2 \\
\hline Locate lower arm position & 1 & 1 \\
\hline Locate wrist position & 2 & 3 \\
\hline Posture score B & 2 & 3 \\
\hline Coupling score & 0 & 0 \\
\hline Score $B$ & 2 & 3 \\
\hline Table C score & 4 & 4 \\
\hline Activity score & 1 & 1 \\
\hline Final Score & 5 & 5 \\
\hline
\end{tabular}

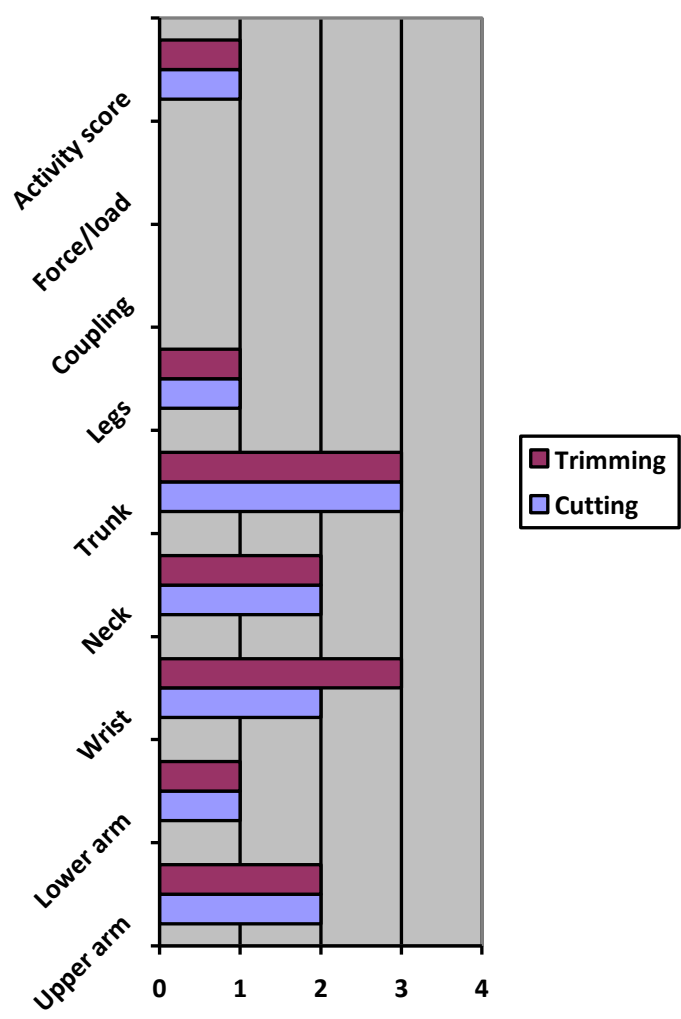

Figure 14 Analysis of the REBA score

The graph in Figure 14 shows the score analysis for each part of the REBA assessment worksheet. The upper arm, lower arm, neck, trunk, leg, force/load and activity scores were the same for both the meat cutting and trimming processes. However, the differences between the scores of the two processes were in terms of the wrist position. The wrist position score for the trimming process was slightly higher than that for the cutting process. Therefore, one can conclude that the meat trimming process affects the wrist position more than the meat cutting process.

Figure 15 shows the comparison between the RULA and REBA scores for the meat cutting and trimming processes. For the meat cutting process, the RULA score was higher than the REBA score. For the meat trimming process, the RULA and REBA scores were the same. Based on the results of the analysis, one can conclude that a butcher's working posture affects the upper part of the body more than the lower part of the body.
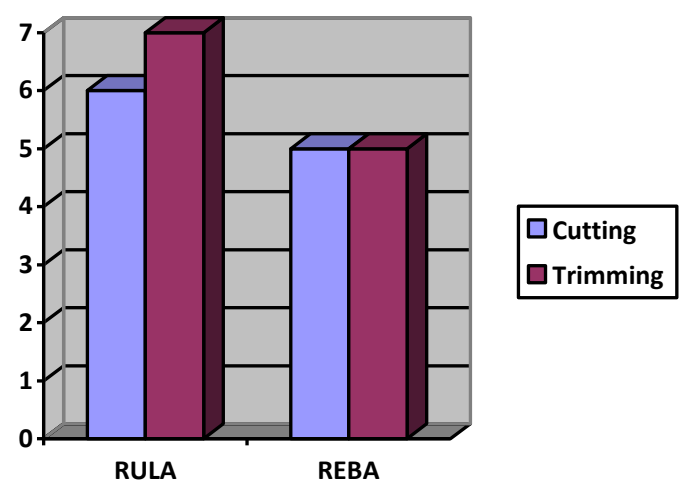

Figure 15 Comparison between a score of RULA and REBA for cutting and trimming process

\subsection{Proposed Design of an Ergonomic Workstation for a Butcher}

Based on the score of RULA and REBA for cutting and trimming process, an ergonomic workstation is needed for a butcher. Figure 16 shows the meat preparation process ergonomic workstation design, in which an ergonomic workstation for a butcher, with the proper working posture, has been proposed. The table height should be between $650 \mathrm{~mm}$ and 950 $\mathrm{mm}$ from the ground as shown in Figure 17; however, the table height is designed to be adjusted based on the butcher's preference. The table is designed with a footrest to support the legs while standing, and anti-fatigue mats to reduce fatigue when standing for a long duration of time. The workstation has been designed based on the principles of motion economy.

Based on these principles, minimized movement is recommended to increase productivity. The workstation is designed to utilize both hands while performing a task, with one hand holding the knife while the other hand is placing the meat on the chopping block. In addition, the principles of motion economy were also applied to the arrangement and design of the tools and equipment, such as the knife. The tools are placed in a location that can be accessed easily by the butcher while maintaining a good working posture. Supported from previous 
research study, it is suggested that ergonomic interventions that address retooling and workstation and process redesign would be useful in reducing the number of injuries [8].

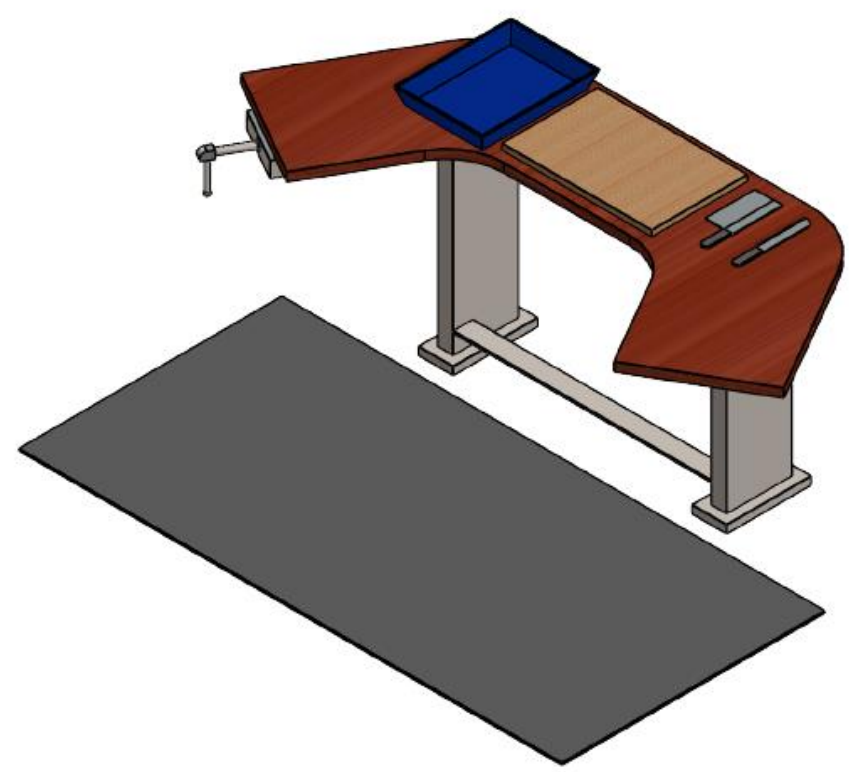

Figure 16 The design of ergonomic workstation for the butcher
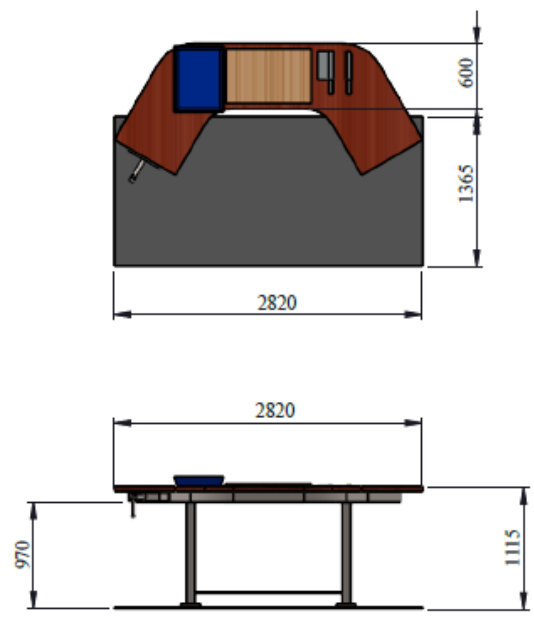

Figure 17 The proposed ergonomic workstation with dimension

\subsection{CONCLUSION}

In this study, the main meat preparation processes of the butcher; cutting and trimming the meat at the SME poultry workstation has been analyzed. During these processes, the work posture of the butcher was examined by using RULA and REBA methods analysis.

Based on the results of the RULA and REBA analyses, a butcher is exposed to a higher risk of working posture problems, such as MSDs and CTDs. Based on RULA analysis, the cutting process score 6 while trimming score 7 . It indicate that the cutting process in consider in medium risk of working posture problem which this activity need further investigation and changes may made soon to make butcher more comfortable while doing the activity. However, trimming process score 7 that highlight that investigation is needed and implement changes is a must. However, the REBA score was 5 for both the meat cutting and meat trimming processes. It consider as a medium risk where further investigation are needed and changes may made soon.

As recommendation, an ergonomic workstation for a butcher has been proposed in order to reduce the risk of work posture problems. The designed workstation is complete with footrest and anti-fatigue mat to reduce fatigue while performing job and all equipment are arranged accordingly with minimum movement and no awkward position by the butcher.

\section{Acknowledgement}

The authors are thankful for the Research University Grant they received, which is a Tier 1 Scheme (Grant No. H250), and the Universiti Tun Hussein Onn Malaysia (UTHM) for the research funding. The authors are grateful to the Faculty of Engineering Technology at the UTHM and Erul Food Industries San Bhd for their research support and opportunities.

\section{References}

[1] Luttmann, A., Jäger, M., Griefahn, B., Caffier, G., Liebers, F., \& Organization, W. H. 2003. Preventing Musculoskeletal Disorders in the Workplace Protecting Workers Health Series no.5, World Health Organization, Switzerland.

[2] Department of Occupational Safety and Health Malaysia, 2017, Guidelines On Ergonomics Risk Assessment At Workplace 2017, Ministy of Human Resource, page 155. Available online: http://www.dosh.gov.my/index.php/en/competentperson-form/occupational-health/garispanduan/ergonomik/2622-01-guidelines-on-ergonomicsrisk-assessment-at-workplace-2017-1 ? path=garispanduan/ergonomik.

[3] Al Madani, D. and Dababneh, A. 2016. Rapid Entire Body Assessment: A Literature Review. American Journal of Engineering and Applied Sciences. 9(1): 107-118. DOI: 10.3844/ajeassp.2016.107.118.

[4] Subramanian, S., Raju, N., Srinivasan, P., Jeganathan, K., \& Jayaraman, S. 2018. Low Back Pain Assessment Using Surface Electromyography Among Industry Workers during 
the Repetitive Bending Tasks. International Journal of Human Factors and Ergonomics. 5(4): 277-292.

DOI: https://doi.org/10.1504/IJHFE.2018.096112

[5] Goodman, G., Kovach, L., Fisher, A., Elsesser, E., Bobinski, D., \& Hansen, J. 2012. Effective Interventions For Cumulative Trauma Disorders of The Upper Extremity In Computer Users: Practice Models Based on Systematic Review. Work. 42(1): 153-172. DOI: 10.3233/WOR201201341.

[6] Panicker, T., Deenathayalan, T., and P. Rajmohan, P. 2017. Ergonomic Evaluation of Work Posture by REBA in Heavy Industries, Advances in Natural and Applied Sciences, 11 (7): 868-873.

[7] Silverstein, B. A., Fine, L. J., \& Armstrong, T. J. 1986. Hand Wrist Cumulative Trauma Disorders in Industry, Occupational and Environmental Medicine. 43(11): 779784. DOI: https://doi.org/10.1016/0003-6870(89)90176-2.

[8] Mukhopadhyay, P. and Khan, A. 2015. The Evaluation of Ergonomic Risk Factors Among Meat Cutters Working In Jabalpur, India. International Journal of Occupational and Environmental Health. 21 (3): 192-198. DOI: https://doi.org/10.1179/2049396714y.0000000064.

[9] Manish, D., Arvind, B., and Sarbjit, S. 2018. Analysis Of Work Related Musculoskeletal Disorders and Ergonomic Posture Assessment of Welders In Unorganised Sector: A Study in Jlandhar India. International Journal of Human Factors and Ergonomics. 5(3): 240-255.

DOI: https://doi.org/10.1504/ijhfe.2018.095913.

[10] Health and Safety Executive of Great Britain. 2017. Workrelated Musculoskeletal Disorders (WRMSDs) Statistics in Great Britain 2017. Health and Safety Exacutive. 1: 1-22. Online http://www.hse.gov.uk/statistics/causdis/msd.pdf.

[11] Kroemer, K. 1989. Cumulative Trauma Disorders: Their Recognition and Ergonomics Measures to Avoid Them, Applied Ergonomics. 20(4): 274-280. DOl: https://doi.org/10.1016/0003-6870(89)90190-7.

[12] Pinto, A. C. C. S., Silva, D.A.S., Ensslin L., Reis, P.F., Vilagra J. M., Vergara, L. G. L. and Moro A. R. P. 2018. Injuries of Repetitive Efforts in Workers from the Poultry Meat Industry: A Bibliometric Analysis of Literature. Sustainability. 10(1): 250, 1-15. DOI: https://doi.org/10.3390/su10010250.

[13] Upasana and Vinay, D. 2017. Work Posture Assessment of Tailors By RULA and REBA Analysis, International Journal of Science, Environment and Technology. 6(4): 2469-2474.

[14] Occupational Health and Safety Council of Ontario, Resource Manual for the MSD Prevention Guideline for Ontario Musculoskeletal Disorder Prevention Series No. 2, 2007. Online manual from: http://www.wsps.ca/WSPS/media/Site/Resources/Downlo ads/msd_2006_guideline_ontario_resource_manual.pdf.

[15] Mahoney, J. 1995. Cumulative Trauma Disorders and Carpal Tunnel Syndrome: Sorting Out the Confusion, Canadian Journal of Plastic Surgery. 3(4): 17-25. DOI: https://doi.org/10.4172/plastic-surgery.1000124.

[16] Singh, J., Lal, H. and Kocher, G. 2012. Musculoskeletal Disorder Risk Assessment in Small Scale Forging Industry by Using RULA Method. International Journal of Engineering and Advanced Technology. 1: 513-518.

[17] McAtamney, L., and Corlett, E. N. 1993. RULA: A Survey Method for the Investigation of World-Related Upper Limb Disorders. Applied Ergonomics. 24(2): 91-99. DOI: https://doi.org/10.1016/0003-6870(93)90080-s.

[18] Hignett, S., and McAtamney, L. 2000. Rapid Entire Body Assessment (REBA). Applied Ergonomics. 31 (11): 201-205. DOI: https://doi.org/10.1201/9780203489925.ch8.
[19] Lohan, N., Nandal, S., and Bhandari, A. 2016. To Study the Principle of Motion Economy in Industry. International Journal of Innovative Research in Technology. 2(8): 104112.

[20] Al-Hakim, L., Sevdalis, N., Maiping, T., Watanachote, D., Sengupta, S., \& Dissaranan, C. 2015. Human Error Identification for Laparoscopic Surgery: Development of a Motion Economy Perspective. Applied Ergonomics. 50: 113-125. DOI: https://doi.org/10.1016/j.apergo.2015.03.00.

[21] Kaya, Ö. 2015. Design of Work Place and Ergonomics in Garment Enterprises. Procedia Manufacturing. 3: 64376443. DOI: https://doi.org/10.1016/j.promfg.2015.07.921

[22] Motamedzade, M., Mohammad, R. A., Rostam, G., and Hossein, M. 2011. Comparison of Ergonomic Risk Assessment Outputs from Rapid Entire Body Assessment and Quick Exposure Check in an Engine Oil Company, Journal Of Research In Health Sciences. 1 (1): 26-32.

DOl: https://doi.org/10.18869/acadpub.johe.2.4.195.

[23] Ansari, N. A. and Sheikh, M. J. 2014. Evaluation of work Posture by RULA and REBA : A Case Study, IOSR Journal of Mechanical and Civil Engineering. 11 (4): 18-23. DOI: https://doi.org/10.9790/1684-11431823.

[24] Wanave, S. B., Bhadke, M. K., and Jibhakate, M. 2014. Study and Validation of Workers Posture in Transformer Manufacturing Industry through RULA. International Journal of Analytical, Experimental and Finite Element Analysis. 1 (7): 62-66.

[25] Nguyen, C. V. 2016. Ergonomic Application to Work Design on Seafood Processing Line. APIEMS 2016 Conference Proceeding.

[26] Norhidayah, M., Mohamed, N. M. Z. N., Mansor, M. A., \& Ismail, A. R. 2016. A Study of Postural Loading in Malaysian Mining Industry using Rapid Entire Body Assessment. MATEC Web Conference. 14: 5-8.

DOI: https://doi.org/10.1051/matecconf/20167400014.

[27] Chowdhury, N. 2015. A Comparative Assessment of Ergonomic Risk Factors in University Personnel Using RULA and REBA Aiming to Study the Cause and Effect Relationship, Master Thesis. Lovisiana State Univiversity. 193. DOI:https://digitalcommons.Isu.edu/gradschool_theses/23 14.

[28] Singh, L. P. 2010. Work Posture Assessment in Forging Industry: An Exploratory Study In India, International Journal of Advanced Engineering Technology. 1 (3): 358366. DOI: IJAET/Vol.I/ Issue III/Oct.-Dec.,2010/358-366.

[29] Sutari, W., Yekti, Y. N. D., \& Astuti, M. D. 2015. Analysis of Working Posture on Muscular Skeleton Disorders of Operator in Stamp Scraping in 'Batik Cap' Industry. Procedia Manufacturing. 4: 133-138. DOI: https://doi.org/10.1016/j.promfg.2015.11.023.

[30] Anwar, N., and George, A. 2015. Study of The Ergonomics of the Worker Using the Rapid Entire Body Assessment Technique on Agri-Machinery Industry. International Journal on Occupational Health \& Safety, Fire Environment-Allied Science. 4(1): 1-4.

DOI: Int J OHSFE-Allied Sci./Vol. 4/Issue 1/Apr-June, 2015/001-004.

[31] Hashim, A. M. and Dawal, S. Z. M. 2013. Evaluation of Students ' Working Postures in School Workshop, International Journal of Ergonomics. 3(1): 25-3. https://doi.org/10.4028/www.scientific.net/aef.10.199.

[32] Marquez, M. 2006. Assessment of Ergonomic Risk Factors in a SME Plastic Injection. Thesis. The Universidad Experimental del Táchira. 1-6. 